Article

\title{
Assessment of a Simplified Connectivity Index and Specific Sediment Potential in River Basins by Means of Geomorphometric Tools
}

\author{
Sergio Grauso ${ }^{1, *}$, Francesco Pasanisi ${ }^{2}$ and Carlo Tebano ${ }^{2}$ \\ 1 ENEA, Italian National Agency for New Technologies, Energy and Sustainable Economic Development, \\ Territorial and Production Systems Sustainability Department, Casaccia Research Centre, \\ Via Anguillarese 301, 00123 Santa Maria di Galeria (Roma), Italy \\ 2 ENEA, Italian National Agency for New Technologies, Energy and Sustainable Economic Development, \\ Territorial and Production Systems Sustainability Department, Portici Research Centre, Piazzale E. Fermi 1, \\ 80055 Portici (NA), Italy; francesco.pasanisi@enea.it (F.P.); carlo.tebano@enea.it (C.T.) \\ * Correspondence: sergio.grauso@enea.it; Tel.: +39-06-3048-4888
}

Received: 28 November 2017; Accepted: 28 January 2018; Published: 30 January 2018

\begin{abstract}
Sediment connectivity is a major topic in recent research because of its relevance in the characterization of the morphology of river systems and assessing of sediment transport and deposition. Currently, the connectivity indices found in the literature are generally dimensionless and need to be coupled with quantitative soil-loss data for land management and design purposes. In the present work, a simple methodology is proposed to assess two different indices, namely, the simplified connectivity index $(S C I)$ and the specific sediment potential $(S S P)$, based on geomorphometric tools that are commonly available in commercial and open-source geographic information system (GIS) platforms. The proposed metrics allows us to easily assess both the SCI and the SSP as functions of the estimated soil erosion per unit area of the catchment and of the inverse distance of each unit area from the river outlet, this distance being measured along the network path. The proposed indices have been devised to express, respectively, the potential sediment transfer ability and the sediment mass potentially available at a given section of the drainage network. In addition to other parameters used to describe the catchment characteristics potentially affecting the river sediment delivery capacity, the SCI and SSP indices can help to refine theoretical models in order to assess the sediment yield $(S Y)$ in ungauged river basins.
\end{abstract}

Keywords: soil loss; sediment yield; connectivity; QGIS; GRASS GIS

\section{Introduction}

Sediment production is the consequence of erosive processes on slopes and river banks, and it is function of a number of variables. With regard to slope erosion, accordingly with the basic concepts of the universal soil loss equation (USLE) and its revised version (RUSLE) [1-3], the main natural variables involved are soil erodibility and rainfall erosivity in combination with slope length and steepness. In addition to natural variables, man-generated factors linked to land use and management also play a role in sediment production. The fate of eroded sediments is being mobilized by runoff and by eventually reaching the closest stream channel where they are transported as sediment load along the river network and then conveyed towards the end destination in depositional environments such as lakes and seas. The presence of sinks, that is, areas of infiltration or sedimentation along this path, prevents a portion of the total amount of sediment produced on slopes (also defined as gross erosion) from reaching the final outlet, where only a fraction of the initial sediment mass is delivered (net erosion). This gap between the net and the gross erosion, commonly quantified by the sediment 
delivery ratio $(S D R)$, is clearly different from one drainage basin to the other. Knowing the true amount of sediment supplied at a given river section is a key factor in many applications. For this reason, the problem of sediment delivery [4,5] has been a subject of studies for many authors who, in the past decades, have developed a number of different prediction models aiming to provide suitable estimates of the SDR. Among others, articles by Ferro \& Minacapilli [6], Dedkov [7], Lu et al. [8], Lenhart et al. [9], Diodato \& Grauso [10], and Vigiak et al. [11] can be quoted regarding this issue. Each of the proposed models has been formulated to explain in a lumped expression the relationship between the sediment yield $(S Y)$ and upland soil erosion in order to convert one quantity into the other as needed. However, the SDR assessment still represents an issue, as it implies numerous uncertainties due to the temporal discontinuity and spatial variability of the involved variables.

Recently, geomorphological research has been directed at investigating and evaluating the sediment connectivity in riverine channel systems at varied-detail scales, also supported by field observations. Sediment connectivity has been defined by Hooke [12] as "the physical linkage of sediment through the channel system" or "the transfer of sediment from one zone to another and the potential for a specific particle to move through the system". The spatial and temporal variability of the connectivity degree has been pointed out together with the intermittent and uneven character of sediment input under variable conditions [12-14]. Significant correlations have been found between connectivity and land cover, precipitation and soil moisture [15].

The concept of connectivity has been reversed in (dis)connectivity when focusing on factors hampering the sediment movement in a catchment, which are differentiated between lateral (from slopes to channels) and longitudinal (along the channel) [16]. Incidentally, a vertical hampering factor such as streambed armouring should also be taken into account. The prominence degree of such hampering factors has been referred to as the "catchment area effectiveness", that is, the proportion of a catchment having the potential to contribute sediment to the river network. This concept implies that not all the parts of a catchment can be considered sediment sources for river transport. This may be generally untrue in the event of extreme floods, when almost all the catchment areas can be virtually considered "effective".

An interesting geographic information system GIS-based approach for the modeling of effective catchment areas has been attempted by Fryirs et al. [16] on the basis of the assumption that the slope angle is the main control factor in sediment delivery. This assumption is founded on the strong link between the slope angle and the stream power in determining the sediment transport. Moreover, unlike other factors, the slope angle can be considered constant, at the time scale of the considered analysis, and can be easily assessed on a geographic basis. In this approach, a suitable slope threshold must be chosen in order to eliminate from the model all those surfaces of the catchment lacking in energy conditions capable of moving materials. The output of this simple GIS-based analysis shows the spatial pattern of potential sediment sources, which are the areas with a slope over the chosen threshold. In this way, the effective catchment area extension can be easily computed and a qualitative degree of connectivity can be ultimately recognized. In addition, the authors address the field-recognition and mapping of all those landforms, such as alluvial fans, floodplains, piedmonts, terraces, bedrock spurs, dams, and so forth, acting as impediments to sediment conveyance and connectivity, pointing out that not only their size and position but also their evolution and age should be assessed, as their function can change over time. On this topic, the role of human infrastructures (dams, terraces, trails, roads, and drainage systems) and land management practices has been pointed out (see e.g., [17,18]).

A true index of connectivity (IC) was proposed by Borselli et al. [19] in a dual form, calculated both in a GIS environment and in the field. With regard to the GIS approach, the IC index was thought in terms of probability that a unit mass of sediment can be transferred from one point along the slope to another point in a permanent drainage line or sink. Ultimately, in the computation of the index (dimensionless), for each elementary cell of the catchment, basic input data, such as the distance between the two points, local gradient, land use - borrowed from the cover management factor (C-factor) of the USLE/RUSLE model - and upslope contributing area, are taken into account. 
Because the index is raster-based to allow for the topographic analysis, the digital elevation model (DEM) resolution and quality can affect the results. For this reason, the index itself needs to be complemented and validated through field observations.

A refinement of the index devised by Borselli et al. [19] was proposed by Cavalli et al. [20], mainly by using a different algorithm for calculating the contributing area and by basing the topographic analysis on very high resolution DEM $(2.5 \mathrm{~m})$ derived by LiDAR data. The fine-scale description of terrain variability allowed the authors to substitute the C-factor, taken as a weighting factor in the original model, with a roughness index. This index, according to the authors, would be more suitable than the C-factor in representing the sediment transport impedance, particularly in non-agricultural and in mountain environments, where surface roughness plays an important role. On the other hand, the raster DEM resolution itself has been proven to heavily influence the hydrological connectivity $[19,21-23]$. This can also change greatly depending on the source used to derive the DEM (e.g., from contour lines, photogrammetric restitution or different remote sensing techniques). The DEM topographic accuracy becomes crucial when assessing the connectivity at a microscale level, to the extent that a new DEM should be derived after any perturbation, for example, a rainfall event [15]. To this aim, high or very high resolution DEMs can adequately be of help.

The IC as proposed by Borselli et al. [19] and Cavalli et al. [20], containing information on elevation, slope, area flow paths and roughness, certainly represents a good indicator for sediment dynamics. On the other hand, the coupling of sediment dynamics and sediment availability, that is, soil-loss data, is of the utmost importance. As an example, a combination of the IC with a soil erosion model has been successfully applied to investigate the effect of sediment connectivity on soil erosion and redistribution in two catchments of Spain [24,25]. Moreover, modeling connectivity patterns, coupled with hydrological distributed models, can help in targeting engineering practices to reduce runoff and land degradation [26].

A morphometric approach has been followed by Sklar et al. [27], who proposed jointing the distribution of elevation, the travel distance and the production rate of a material from every unit area (be it water, solutes or sediment) in a single catchment integral to obtain the "catchment power", that is, a parameter expressing the rate of potential energy dissipation from source areas to the outlet along flow paths.

A different quantitative approach towards sediment connectivity description has been attempted by means of mathematical graph theory and numerical simulation models of sediment sources, pathways and sinks $[15,28,29]$.

Further improvement can be derived from DEMs of Difference (DoD) analysis in order to include information on potential sediment pathways in morphological sediment budgets [30].

Developing knowledge about connectivity has led to the conclusion that, to practical aims, the more easily an IC is computed, the more appreciated it will be in application studies and land management. Giving attention to stakeholders and decision-makers, the 2012-2015 SedAlp project [31], in the framework of the European Territorial Cooperation Alpine Space, has been focused on management problems related to sediment formation and transfer in alpine basins.

Currently, the 2014-2018 Connecteur project [32], supported by the EU Framework Programme Horizon 2020, aims to gather together existing expertise in the field of connectivity in order to transfer the current understanding into useable science by developing a series of monitoring and modeling tools for the management of catchment systems. In this framework, the SedInConnect tool has been recently developed and made available for computation of the IC [33].

On the basis of the above findings, the present work was inspired by the need to integrate a set of variables, derived from the geomorphometric analysis of a number of drainage basins, with the information regarding the potential sediment supply. This action was carried out in the framework of an underway research aiming to develop a refined regression model to estimate the river $S Y$ in Italian ungauged catchments. When comparing different catchments, other conditions being equal (size and shape of drainage basin, network arrangement, slope, etc.) and the areal distribution of sediment 
sources, that is, their distance from the reference outlet (as well as from the main channel), are quite important in determining the degree of $S Y$. This distance is more correctly evaluated considering the real path through the stream network. This requirement led us to develop a simplified methodology, according with the conceptual assumptions of the mentioned literature, that is helpful to easily assess the catchment connectivity by means of available digital cartographic data and GIS tools. Moreover, the publication of the Map of Soil Loss by Water Erosion in the European Union [34], encompassing the product of the USLE variables, encouraged us to utilize this database, suitably modified as described in the following.

As an example of application, three small river basins, located in different regions of southern Italy, are here treated to illustrate the procedure and compare the results in order to analyze the significance of the proposed indices.

\section{Materials and Methods}

\subsection{Basic Concept}

The rationale of the methodology presented here is given by considering the amount of hillslope soil loss per unit area of the catchment as the basic information about the catchment sediment supply potential. At the same time, considering the re-depositional processes occurring along slopes and stream beds, an attenuation factor must be taken into account in order to correctly associate the soil-loss datum (SL) to the net amount of sediment delivered at the outlet (SY). To this aim, besides the role played by the aforementioned variables and processes (local relief, stream gradient, topographic roughness, etc.) potentially affecting the river sediment delivery capacity, the relative distance of sediment sources from the outlet, via the river network, can be viewed as an attenuation factor of immediate perception, as also suggested by the downslope component of the IC by Borselli et al. [19]. In this sense, a source of a large amount of sediment can contribute little to the $S Y$ if it is located far from the outlet, because of a greater probability of sediment re-deposition. On the contrary, a source of relatively few sediments can contribute significantly if close to the outlet. Thus, an inverse proportionality could be hypothesized between the source distance and net $S Y$. This is in agreement with the general assumption that the area-specific $S Y$, as well as $S D R$, is inversely correlated to the drainage basin area [5,35-38]. Therefore we can assume that the soil loss rate per each unit source area of the catchment $\left(S L_{i}\right)$ divided by its distance from the outlet $\left(d_{\mathrm{i}}\right)$ can represent, in a simple index form, the effective sediment potential $\left(S P_{i}\right)$ provided by that single source area to sediment delivery. The simple mean of total $S P_{i}$ contributions could be then considered in order to derive a single index representing the true capacity of a catchment as a whole to transfer sediment from the sources to the outlet, that is, the sediment connectivity. However, to obtain a dimensionless index allowing us to compare the results from different catchments, both $S L_{i}$ and $d_{i}$ may be normalized through their ratio to the respective maximum values, and then the arithmetic mean of the normalized $S P_{i}$ may be calculated. The "simplified connectivity index" $(S C I)$ can be finally expressed as the cologarithm of the mean $S P_{i}$ obtained, so as to provide more intuitive and suitable values:

$$
S C I=\operatorname{colog}\left(\frac{\sum_{i=1}^{N} \frac{S L_{i} / S L_{\max }}{d_{i} / d_{\max }}}{N}\right)
$$

where

- $S L_{i}$ is the specific soil loss from the $i$ th unit area;

- $S L_{\max }$ is maximum specific soil loss;

- $d_{i}$ is distance of the $i$ th unit area from the outlet;

- $d_{\max }$ is maximum distance from the outlet;

- $\quad N$ is the total number of unit areas. 
One more index can be proposed, which is capable of representing the specific sediment potential of the overall catchment (SSP). This index can be derived by a weighted arithmetic mean of $S L_{i}$ over the entire catchment, assuming as weight the inverse distance $1 / d_{i}$, that is, that which influences the mean of the total sediment contributions from hillslope soil erosion:

$$
S S P=\frac{\sum_{i=1}^{N} w_{i} \cdot S L_{i}}{\sum_{i=1}^{N} w_{i}}
$$

where $w_{i}=1 / d_{i}$.

In this case, the index will have the same dimensions as the soil-loss rate (e.g., $\left.\mathrm{t} \times \mathrm{ha}^{-1} \times \mathrm{y}^{-1}\right)$, inasmuch as the SSP will represent the specific sediment amount produced from the upslope catchment area and effectively available at a given stream section.

Both the proposed indices are meant to be computed on a geographic basis, namely, in a GIS environment in which geospatial data can be analyzed in digital format.

To proceed with the SCI and the SSP calculation for a given catchment, a dataset of distributed soil loss and relative distances from the outlet must be prepared. More precisely, a soil-loss digital map of the concerned catchment is necessary to this aim. Such a map can be preliminarily built up, if enough data are available, by means of suitable models applicable at the catchment scale. However, as a result of the efforts made by several institutions at national and supranational levels, the information about long-term average soil loss is currently available at varied-detail scales in Europe. The Map of Soil Loss by Water Erosion in the European Union recently published by Panagos et al. [34] can be useful for this purpose. The map provides the amount of soil loss in metric tons per hectare per year, in a $100 \mathrm{~m}$ resolution (1 ha surface area) raster format, as a result of the application of a modified version of the RUSLE model. In fact, the data provided in this map take into account the main natural and human variables, previously cited in the introduction, affecting the sediment production on slopes. Moreover, the soil-loss information is discretized cell by cell of the raster map; that is, the specific soil loss $S L_{i}$ per unit area is provided. Therefore, these data are suitable and ea $S Y$ to use for quantifying the gross erosion contributing to river $S Y$.

As mentioned above, dealing with sediment transported by rivers, the distance from sediment sources to the outlet should be computed along the river network so as to emulate the true pathway of sediment particles charged in the watercourses. Therefore, another geographic information layer to be provided is that representing the river network. Vector hydrographic layers can be procured from different sources: as commercial products, supplied by official cartographic providers or self-produced by digitalizing the blue-lines drawn on official topographic maps. The river network lines can also be generated by automatic extraction from a DEM. For this purpose, specific geoalgorithms and other tools commonly available in GIS platforms can be used. In this case, a river network is generated in raster format and is converted into vector format, as pointed out from here forward.

Lastly, the point vector layer containing the outlet is needed in order to define the sediment delivery point geographically. In fact, this can be chosen at any point of the river network, wherever it can be of interest (e.g., for design purposes, at a hypothetical dam section, at the intersection with a road or main channel as well as at the mouth on a coastline, etc.). Therefore, given any selected point, this will be considered as the reference outlet. The related layer can be easily produced on the basis of the river network layer itself by digitalizing, inside the GIS operating window, the outlet of interest along the network and saving it as a new vector point layer.

\subsection{Available GIS Tools}

The GIS platform referred to here is the QGIS open-source software (version 2.18) [39] with its functions and add-on geoalgorithms, including GRASS GIS modules [40]. The procedure proposed here requires that all the considered layers must be provided in vector format. This is consistent with the choice to work with stream networks derived from blue lines of available topographic maps, which, 
according to our experience, can be considered more realistic than the stream network automatically extracted from a DEM using raster-based GIS tools, above all, in flat areas. Therefore, the soil erosion raster map needs to be transformed into a vector file. In the QGIS environment, one function suitable to this aim is the format conversion provided in the Raster menu of the graphical user interface. At the end of the process, a point layer will be created where the unit cells of the original raster layer are substituted by their centroids, that is, regularly distributed points, centered in the cells whose attributes are their spatial coordinates $(x, y)$, and the associated SL. These attributes are reported in columns in the joined table (field_1, field_2 and field_3). In the same table, a new column shall be created and named distance; it will be filled in the successive step of the procedure (Figure 1).

At this point, the re-formatted soil loss, together with the river network and outlet vector layers, can be uploaded in the GIS operating window to proceed with the elaboration. The first operation is to connect the soil-loss centroids with the river network. For this purpose, the GRASS geoalgorithm v.net.connect can be selected from the QGIS Processing Tools panel. This module, by default, creates new lines connecting each point to the closest line of the river network (Figure 2).

Attention must be paid in choosing a suitable threshold value for the connection distance as required in the v.net.connect mask, in order to be sure that all centroids are effectively connected. To know the distance separating each soil-loss centroid from the river outlet, the complete arcs encompassing the new point-line connections and the original network lines should be measured. In this case, the GRASS module v.net.distance is suitable, as it specifically computes the shortest distance, via the network, between two sets of points and adds it to the attribute table in a column dist (Figure 3).

Subsequently, the GRASS geoalgorithm v.what.vect is launched via the QGIS Processing Tools panel while keeping the soil-loss centroid layer as the input vector, whose attribute table should be edited; in this case, the column distance is to be filled, while the vector to be queried is the distance vector just created. A new point layer is thus generated whereby the information contents of the two original layers are joined together. Consequently, the final attribute table will contain, for each point, the geographical coordinates (field_1 and field_2), the soil-loss amount (field_3) and the distance from the outlet (distance), as shown in Figure 4. The table can be then exported into an electronic spreadsheet to which mathematical functions can be easily applied.

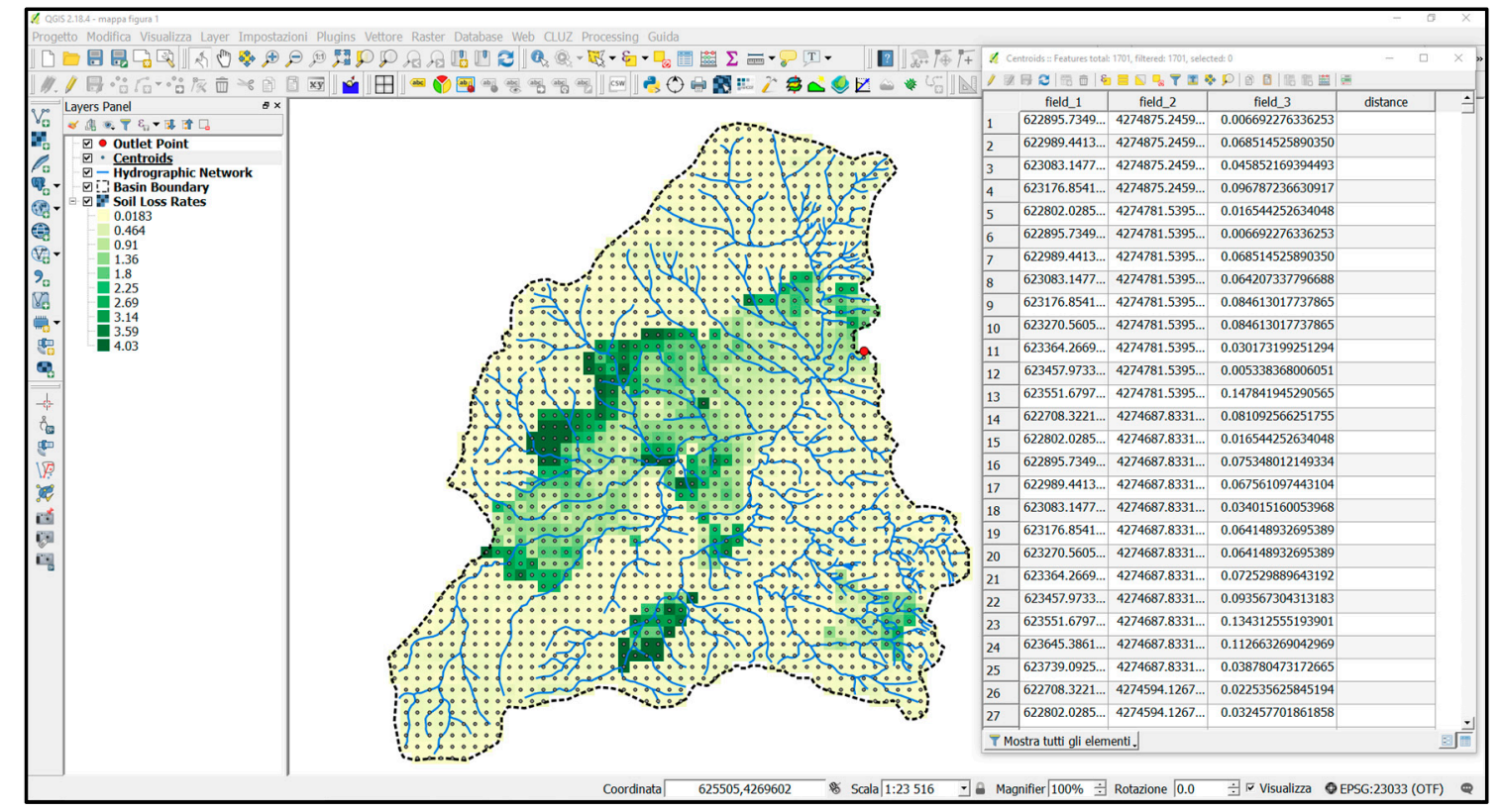

Figure 1. Soil-loss point layer (centroids) converted from raster map. 


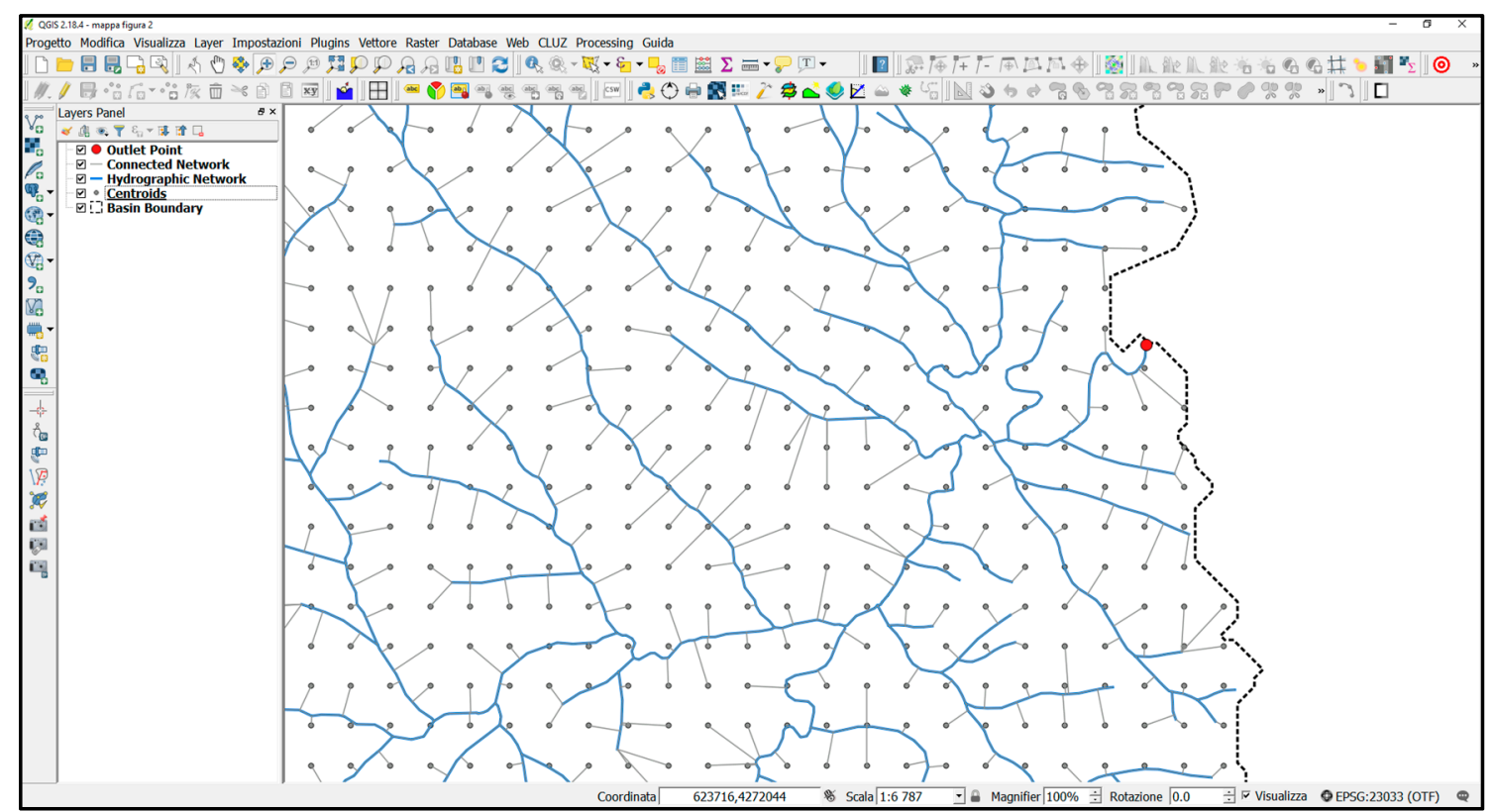

Figure 2. Result of the v.net.connect tool: new lines connecting centroids to stream network.

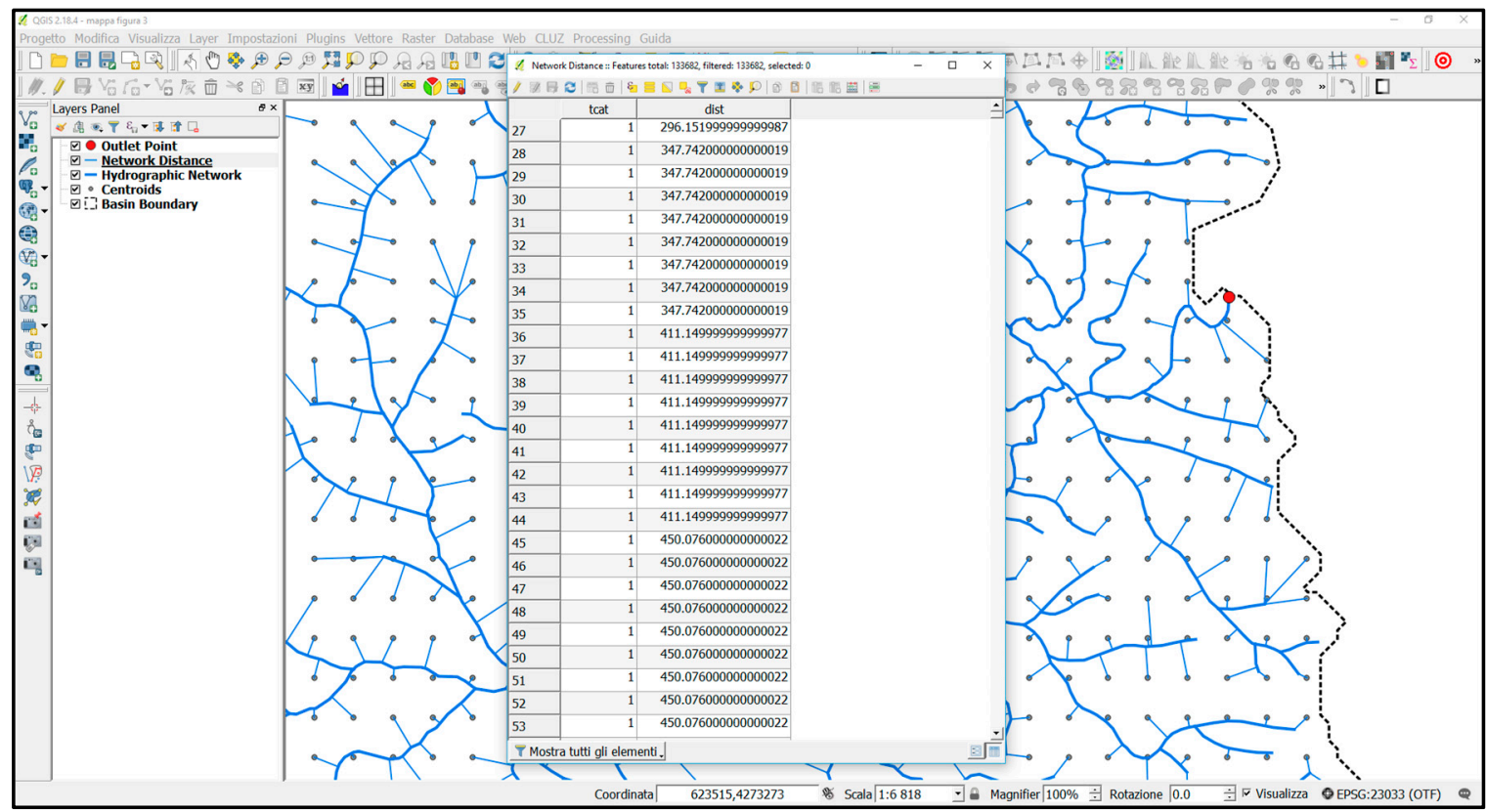

Figure 3. Result of the v.net.distance tool: the distances between centroids and outlet along the network arcs are computed and added to the attribute table. 


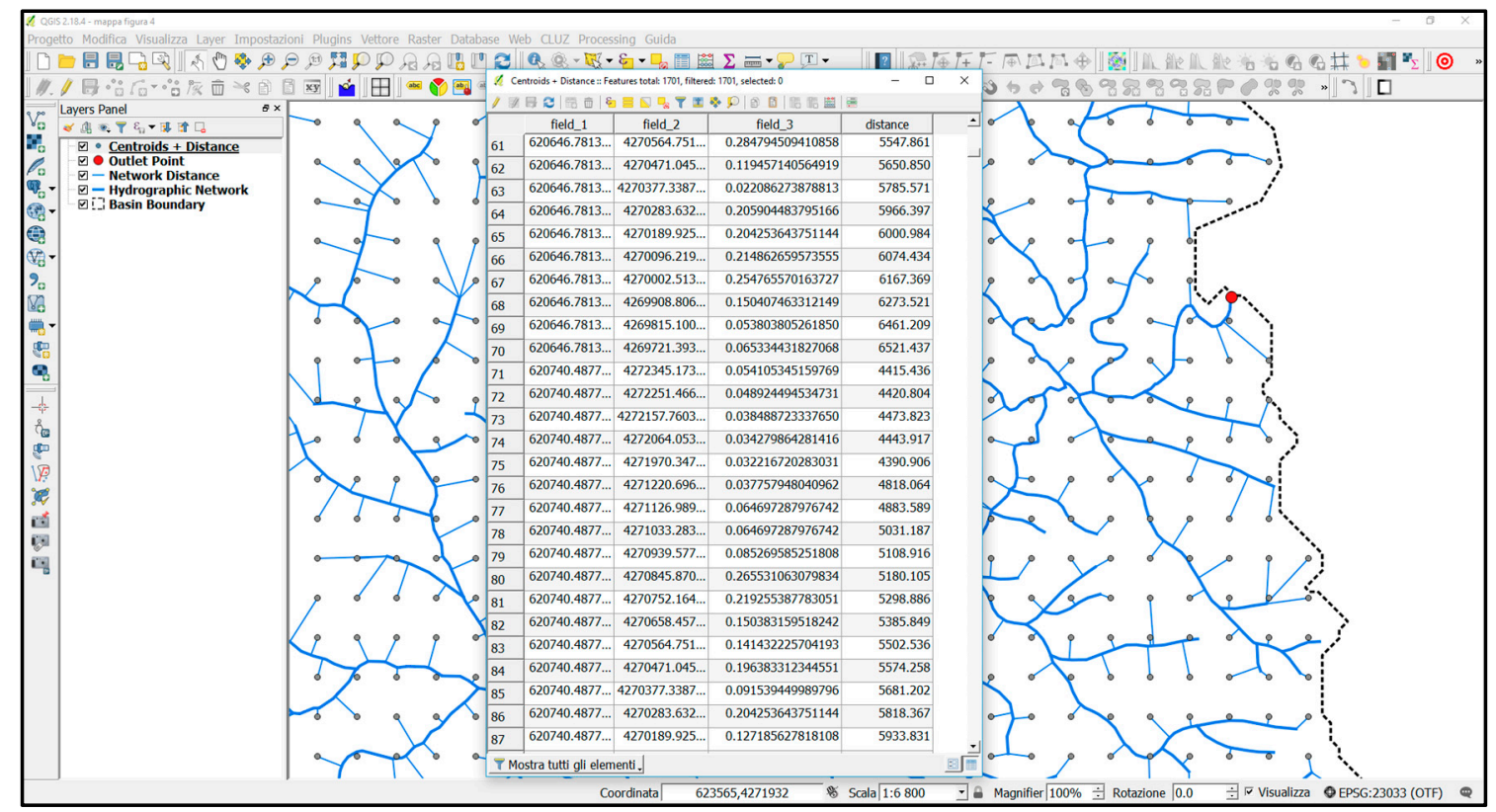

Figure 4. The new centroid layer integrated by the "distance" information.

\section{Results and Discussion}

The selected test catchments, namely, the upper Alaco, the Lapilloso and the upper Imera catchments, represent the upper valley sections of the main drainage basins, subtended by the existing hydrometric gauging stations of the National Italian Hydrographic Network. The geographical setting of the catchments is displayed in Figure 5, while Figure 6 illustrates the shape of the basins, the hydrographic network, and the location of gauging stations. The suspended SY data utilized for the present examples are referred to observation periods spanning from 11 to 18 years.

The upper Alaco stream catchment flows through the "Serre calabresi", a hilly and mountainous area in the Calabrian Apennine characterized by high-density forest coverage. It shows an intermediate circular elongated shape. The river network is superimposed on highly fractured, lowly erodible Palaeozoic granitic bedrock covered by Cambisol-Leptosol soil associations. The soil-loss rate is poor, despite the relatively dense stream network.

The Lapilloso stream catchment is a side-portion of the Venosa catchment, a tributary of the Ofanto major river flowing through the Adriatic side of southern Italy. The bedrock is mainly composed of flysch units of Palaeogene-Miocene age (marly sandstones, limestones and shales, in equal distribution) and the area limited to the final part of the catchment, close to the outlet, is composed by sands, conglomerates and clays of Pliocene-Pleistocene age. The soil cover is given by Cambisols-Regosols. Most of the catchment area is occupied by agriculture, mainly non-irrigated arable land, while the minor part is forestland. The catchment is characterized by an elongated shape and moderate soil-loss rate on average.

The upper Imera catchment represents the extreme upper valley of the Southern Imera River, one of the main rivers in Sicily. Almost the entire catchment is found on marly sandstone flysch rocks of Palaeogene age with Lithosol and Eutric Cambisol covers. The basin area is nearly circle-shaped and is mostly covered with sclerophyllous vegetation, mixed forests and natural grasslands. The soil-loss rate is moderate. 


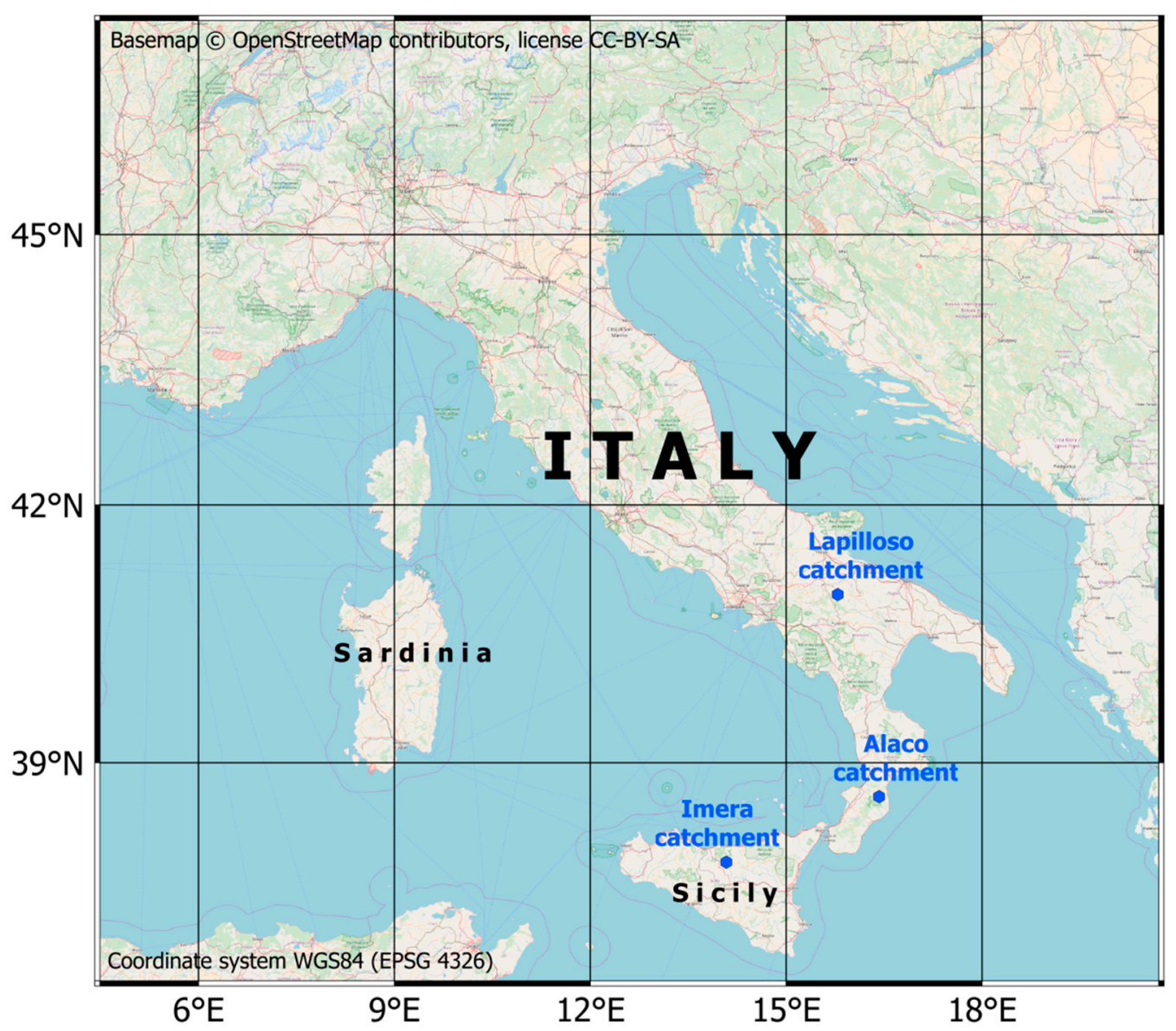

Figure 5. Geographical setting of test catchments.
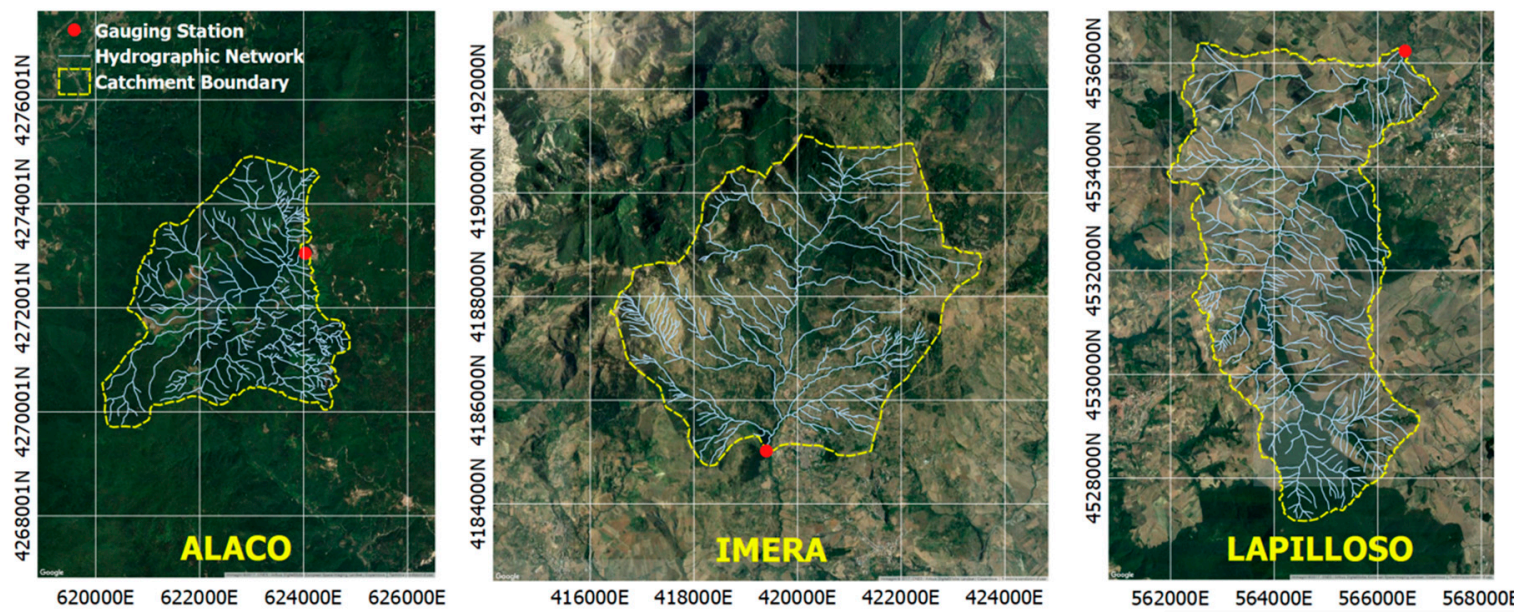

Figure 6. Catchment boundaries, hydrographic networks, and locations of gauging stations. Coordinate system ED50-UTM33N (EPSG 23033). Basemap Google Maps, satellite images, 2017, CNES/Airbus, DigitalGlobe, European Space Imaging, Landsat/Copernicus.

All the selected catchments lie under a Mediterranean climate with a low rainfall concentrated in winter and spring. In particular, the upper Imera catchment shows characteristics of a dry subarid climate. The water flow is strictly influenced by the rainfall distribution and intensity; therefore, the streams commonly show a torrent-like regime with large intra- and inter-annual discharge variations. In Table 1, the main morphometric characteristics of the selected catchments, computed by 
means of the QMorphoStream GIS tool [41], are summarized. A $20 \times 20 \mathrm{~m}$ resolution DEM publicly available on the Italian National Geoportal [42] was used in the present analysis.

Table 1. Morphometrics of selected catchments.

\begin{tabular}{cccc}
\hline Physical Characters & Alaco & Lapilloso & Imera \\
\hline Perimeter $(\mathrm{km})$ & 19.4 & 31.3 & 22.9 \\
Area $\left(\mathrm{km}^{2}\right)$ & 14.9 & 28.9 & 28.5 \\
Max elevation (m above sea level) & 1259 & 815 & 1826 \\
Min elevation (m a.s.l.) & 971 & 305 & 798 \\
Mean elevation (m a.s.l.) & 1048 & 554 & 1226 \\
Elevation Range (m) & 288 & 510 & 1028 \\
Max elongation (km) & 5.0 & 9.3 & 6.6 \\
Streams' total length (km) & 92.9 & 141.6 & 117.7 \\
Stream frequency (km $\left.{ }^{-2}\right)$ & 22.7 & 10.9 & 10.1 \\
Drainage density (km $\left.{ }^{-1}\right)$ & 6.22 & 4.90 & 4.13 \\
Fournier's orographic coeff. & 0.073 & 0.011 & 0.053 \\
Hypsometric integral & 0.295 & 0.413 & 0.390 \\
Circularity ratio & 0.497 & 0.370 & 0.679 \\
Relief ratio & 0.250 & 0.088 & 0.278 \\
Elongation ratio & 0.867 & 0.652 & 0.918 \\
\hline
\end{tabular}

The soil-loss layers of the test catchments were derived by intersecting and cutting the European Soil Erosion Map [34] by the watershed polygons (Figure 7). The river networks were derived by vectorizing the blue lines from 1:25,000 official topographic maps provided by the Italian Army's Geographic Institute (IGMI). A quick validation check and editing of network lines were performed by means of orthophoto images of suitable resolution, also available on the National Geoportal [42].
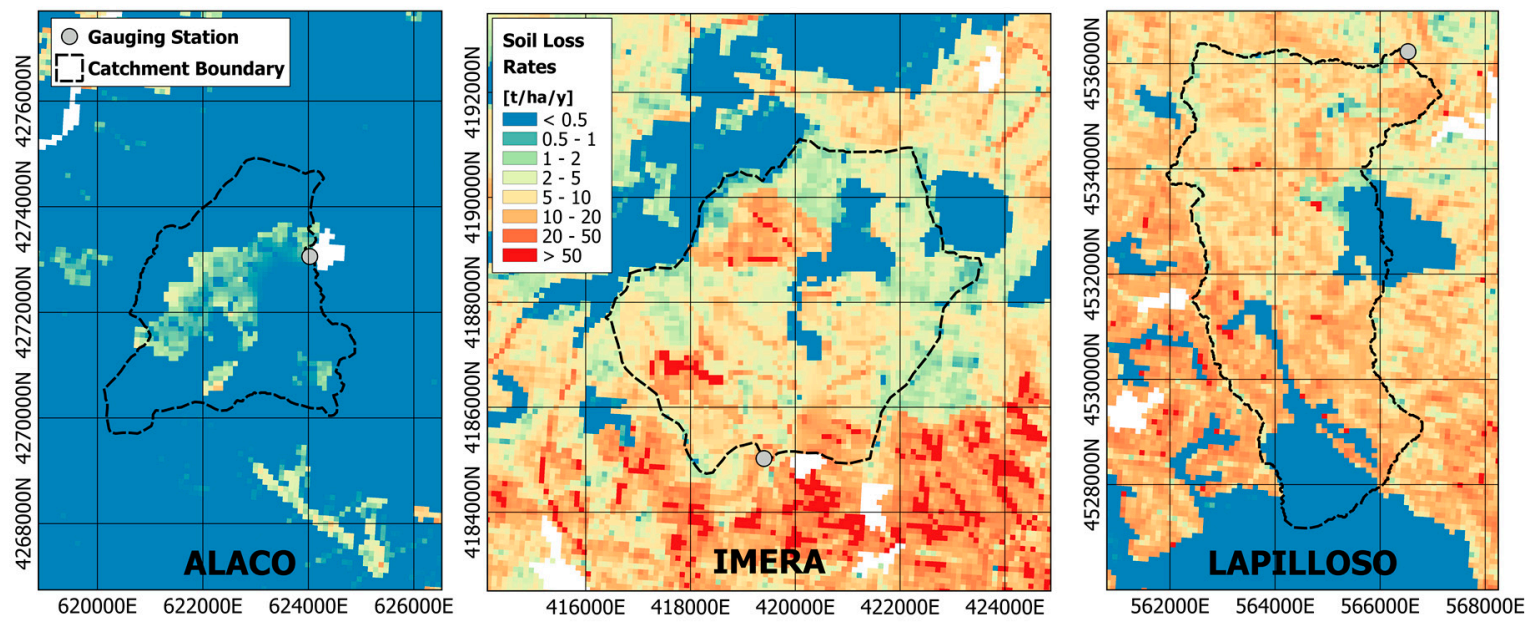

Figure 7. Catchment soil-loss maps derived from the Soil Erosion Map of Europe [34]. Coordinate system: ED50-UTM33N (EPSG 23033).

The results of the GIS procedure for computing the SCI and the SSP are reported in Table 2. In the last row of the table, the SDRs are also reported, given by the ratio of the measured $S Y$ to the total gross soil loss.

As can be seen, on the basis of Equation (1), the Alaco catchment showed the best connectivity, likely as a result of the shorter mean distance from the outlet compared to the other two examined catchments. Moreover, despite the very low average soil-loss rate, which did not increase substantially even if the SSP was taken into account, the specific sediment yield (SSY) measured on the Alaco stream was even higher than the mean soil loss in the catchment. This fact can theoretically indicate that 
stream bed erosion can occur, adding material to the sediment load, and it may likely happen during the occasion of flooding. As a consequence, this ratio produced a SDR greater than 1, which seems consistent with the SCI value. Conversely, the connectivity shown by the Lapilloso catchment, which is characterized by an elongated shape, was the lowest.

Table 2. Mean soil loss (SL), connectivity indices (SSP and SCP), mean sediment source distance from outlet $(d)$, mean specific sediment yield (SSY) and sediment delivery ratio (SDR) of selected catchments.

\begin{tabular}{cccc}
\hline Catchment Quantities and Indices & Alaco & Lapilloso & Imera \\
\hline$S L\left(\mathrm{ha}^{-1} \cdot \mathrm{y}^{-1}\right)$ & 0.59 & 13.60 & 11.39 \\
$S C I$ & 1.05 & 0.25 & 0.74 \\
$S S P\left(\mathrm{t} \cdot \mathrm{ha}^{-1} \cdot \mathrm{y}^{-1}\right)$ & 0.615 & 14.28 & 13.18 \\
$d\left(\mathrm{~km}^{-1}\right.$ & 3.40 & 7.12 & 4.65 \\
$S S Y\left(\mathrm{t} \cdot \mathrm{ha}^{-1} \cdot \mathrm{y}^{-1}\right)$ & 0.703 & 0.337 & 1.915 \\
$S D R$ & 1.05 & 0.03 & 0.15 \\
\hline
\end{tabular}

In all the examined cases, there were slight differences between the soil-loss contribution calculated by the simple arithmetical average (first row in the table) and the SSP averaged using the formula (2). However, the latter was higher than the former. This element points out that, from all the examined cases, the ratio of sediment loss/distance was favorable to sediment availability, proving that averaging the catchment soil loss by Equation (2) allows us to obtain more reliable estimates of the sediment potential compared to the simple mean of the specific soil-loss data. The figures show how the most erodible areas in the three catchments were indeed located close to the mainstream or in the final part of the catchment around the outlet. Thus, the mean available sediment amount should have been higher than the simple average of the total soil loss. This difference was more evident in the upper Imera catchment, with a relative increase of about $16 \%$, while the increase in the Alaco and Lapilloso catchments was $4 \%$ and 5\%, respectively. Although the Lapilloso and the Imera catchments have the same area extent and both the sediment loss and SSP were somewhat larger in the Lapilloso than in the Imera catchment, the measured SSY was much larger in the latter. This is consistent with the lower IC of the Lapilloso catchment, which affects the sediment transfer along the stream network. In addition, considering the already mentioned elongated shape of the Lapilloso catchment, one can conclude that the IC is also consistent with the catchment shape. Incidentally, the missing SY in the Lapilloso catchment, and, consequently, the IC, can also be related to its very low relief ratio, coherently with the general law observed in small drainage basins [43].

One possible criticism to the described procedure and results could come from the adopted GIS tools. In fact, the suggested v.net.connect tool works bidimensionally on the shortest distances from the river network and does not take into account the true hydrological connection of the soil-loss point features with respect to drainage lines. This can imply, in some cases, that a single point can be connected to a stream rather than to another, despite the fact that the cell it belongs to is not actually drained by that stream, because it can lie, in whole or in part, beyond its water divide. This may be simply verified by overlaying the raster soil-loss map and the vector centroid layer on a DEM of suitable resolution. However, after an accurate check, we may argue that, in the cases examined here, this circumstance is rather infrequent and can produce a negligible effect; therefore we consider that the procedure herewith presented is reliable and can provide satisfactory results. A specific GIS function could be implemented in order to improve the connections between centroids and the stream network accordingly with the true hydrological scheme, but this would be the object of further research.

\section{Conclusions}

Two different indices, the SCI and the SSP index, have been developed, on the basis of the estimated soil-loss data and the inverse distances of sediment sources from the river outlet. The purpose 
was to express, in simplified form, two basic characteristics of a catchment, that is, the sediment transfer capacity and the potentially available sediment amount via the river network.

Although the proposed indices are both related to the distance from the outlet, the first is in the form of an adimensional index, while the second represents the weighted mean of the soil loss $\left(\mathrm{t} \cdot \mathrm{ha}^{-1} \cdot \mathrm{y}^{-1}\right)$ at the catchment scale.

Despite possible shortcomings linked to the functionality of the suggested GIS tools, which are proved to be of marginal significance, the ease of the GIS approach and the use of available databases and tools make the methodology usable and repeatable.

The discussed results have pointed out the complementarity between the proposed indices, which may be used together or alternatively as a proxy for the sediment potential of a catchment. More specifically, in combination with geomorphometric and hydrological parameters, in order to comprise the whole range of variables affecting the $S Y$, these indices can help in refining theoretical models for the assessment of the $S Y$ in ungauged river basins.

Acknowledgments: The authors thank the European Soil Data Centre (ESDAC) (https:/ / esdac.jrc.ec.europa.eu/), European Commission, Joint Research Centre, for making available the soil-loss data. The authors also thank the anonymous reviewers for their valuable comments and suggestions.

Author Contributions: Sergio Grauso is the main author who initiated the idea and wrote the manuscript; Francesco Pasanisi and Carlo Tebano performed the GIS elaborations and model implementation and contributed to the final writing of the manuscript.

Conflicts of Interest: The authors declare no conflict of interest.

\section{References}

1. Wischmeier, W.H.; Smith, D.D. Predicting rainfall erosion losses-A guide to conservation planning. In US Department of Agriculture, Agriculture Handbook No. 537; US Government Printing Office: Washington, DC, USA, 1978.

2. Renard, K.G.; Foster, G.R.; Weesies, G.A.; Porter, J.P. RUSLE—Revised universal soil loss equation. J. Soil Water Conserv. 1991, 46, 30-33.

3. Renard, K.G.; Foster, G.R.; Weesies, G.A.; McCool, D.K.; Yoder, D.C. Predicting soil erosion by water-A guide to conservation planning with the revised universal soil loss equation (RUSLE). In US Department of Agriculture, Agriculture Handbook No. 703; US Government Printing Office: Washington, DC, USA, 1997.

4. Wolman, M.G. Changing needs and opportunities in the sediment field. Water Resour. Res. 1977, 13, 50-54. [CrossRef]

5. Walling, D.E. The sediment delivery problem. J. Hydrol. 1983, 65, 209-237. [CrossRef]

6. Ferro, V.; Minacapilli, M. Sediment delivery processes at basin scale. Hydrol. Sci. J. 1995, 40, $703-717$. [CrossRef]

7. Dedkov, A. The relationship between sediment yield and drainage basin area. In Sediment Transfer through the Fluvial System, Proceedings of the International Symposium Held in Moscow, Russia, 2-6 August 2004; IAHS Publications: Wallingford, UK, 2004.

8. Lu, H.; Moran, C.; Prosser, I.; Sivapalan, M. Modelling sediment delivery ratio based on physical principles. In Proceedings of the 2nd International Congress on Environmental Modelling and Software, Osnabrück, Germany, 14-17 June 2004.

9. Lenhart, T.; Van Rompaey, A.; Steegen, A.; Fohrer, N.; Frede, H.-G.; Govers, G. Considering spatial distribution and deposition of sediment in lumped and semi-distributed models. Hydrol. Process. 2005, 19, 785-794. [CrossRef]

10. Diodato, N.; Grauso, S. An improved correlation model for sediment delivery ratio assessment. Environ. Earth Sci. 2009, 59, 223-231. [CrossRef]

11. Vigiak, O.; Borselli, L.; Newham, L.T.H.; McInnes, J.; Roberts, A.M. Comparison of conceptual landscape metrics to define hillslope-scale sediment delivery ratio. Geomorphology 2012, 138, 74-88. [CrossRef]

12. Hooke, J. Coarse sediment connectivity in river channel systems: A conceptual framework and methodology. Geomorphology 2003, 56, 79-94. [CrossRef] 
13. Pilotti, M.; Bacchi, B. Distributed evaluation of the contribution of soil erosion to the sediment yield from a watershed. Earth Surface Process. Landf. 1997, 22, 1239-1251. [CrossRef]

14. Cammeraat, L.H. A review of two strongly contrasting geomorphological systems within the context of scale. Earth Surface Process. Landf. 2002, 27, 1201-1222. [CrossRef]

15. Masselink, R.J.H.; Heckmann, T.; Temme, A.J.A.M.; Anders, N.S.; Gooren, H.P.A.; Keesstra, S.D. A network theory approach for a better understanding of overland flow connectivity. Hydrol. Process. 2017, 31, 207-220. [CrossRef]

16. Fryirs, K.A.; Brierley, G.J.; Preston, N.J.; Spencer, J. Catchment-scale (dis)connectivity in sediment flux in the upper Hunter catchment, New South Wales, Australia. Geomorphology 2007, 84, 297-316. [CrossRef]

17. Gumiere, S.J.; Le Bissonnais, Y.; Raclot, D.; Cheviron, B. Vegetated filter effects on sedimentological connectivity of agricultural catchments in erosion modelling: A review. Earth Surface Process. Landf. 2011, 36, 3-19. [CrossRef]

18. López-Vicente, M.; Nadal-Romero, E.; Cammeraat, L.H. Hydrological connectivity does change over 70 years of abandonment and afforestation in the Spanish Pyrenees. Land Degrad. Dev. 2016, 28, 1298-1310. [CrossRef]

19. Borselli, L.; Cassi, P.; Torri, D. Prolegomena to sediment and flow connectivity in the landscape: A GIS and field numerical assessment. Catena 2008, 75, 268-277. [CrossRef]

20. Cavalli, M.; Trevisani, S.; Comiti, F.; Marchi, L. Geomorphometric assessment of spatial sediment connectivity in small Alpine catchments. Geomorphology 2013, 188, 31-41. [CrossRef]

21. Brardinoni, F.; Cavalli, M.; Heckmann, T.; Liébault, F.; Rimböck, A. Guidelines for Assessing Sediment Dynamics in Alpine Basins and Channel Reaches. Available online: http:/ / www.sedalp.eu/download/ dwd/reports/WP4_Report.pdf (accessed on 6 November 2017).

22. López-Vicente, M.; Álvarez, S. Influence of DEM resolution on modelling hydrological connectivity in a complex agricultural catchment with woody crops. Earth Surface Process. Landf. 2017. [CrossRef]

23. Cantreul, V.; Bielders, C.; Calsamiglia, A.; Degré, A. How pixel size affects a sediment connectivity index in central Belgium. Earth Surface Process. Landf. 2017. [CrossRef]

24. López-Vicente, M.; Poesen, J.; Navas, A.; Gaspar, L. Predicting runoff and sediment connectivity and soil erosion by water for different land use scenarios in the Spanish Pre-Pyrenees. Catena 2013, 102, 62-73. [CrossRef]

25. López-Vicente, M.; Quijano, L.; Palazón, L.; Gaspar, L. Assessment of soil redistribution at catchment scale by coupling a soil erosion model and a sediment connectivity index (Central Spanish Pre-Pyrenees). Cuad. Investig. Geogr. 2015, 141, 127-147. [CrossRef]

26. Cammeraat, L.H.; van Beek, L.P.H.; Dooms, T. Modelling Water and Sediment Connectivity Patterns in a Semi-Arid Landscape. Available online: https://pure.uva.nl/ws/files/1083710/71066_murcia.pdf (accessed on 6 November 2017).

27. Sklar, L.S.; Riebe, C.S.; Lukens, C.E.; Bellugi, D. Catchment power and the joint distribution of elevation and travel distance to the outlet. Earth Surface Dyn. 2016, 4, 799-818. [CrossRef]

28. Heckmann, T.; Schwanghart, W. Geomorphic coupling and sediment connectivity in an alpine catchment-Exploring sediment cascades using graph theory. Geomorphology 2013, 182, 89-103. [CrossRef]

29. Cossart, É.; Fressard, M. Assessment of structural sediment connectivity within catchments: Insights from graph theory. Earth Surface Dyn. 2017, 5, 253-268. [CrossRef]

30. Heckmann, T.; Vericat, D. Inferring sediment connectivity from high-resolution DEMs of Difference. In Proceedings of the European Geosciences Union General Assembly 2017, Vienna, Austria, 23-28 April 2017.

31. SedAlp Project. Sediment Management in Alpine Basins. Available online: http:/ / www.sedalp.eu/project/ (accessed on 6 November 2017).

32. Connecteur Project. Connecting European Connectivity Research (COST Action No. ES1306). Available online: http:/ / connecteur.info/ (accessed on 6 November 2017).

33. Crema, S.; Cavalli, M. SedInConnect: A stand-alone, free and open source tool for the assessment of sediment connectivity. Comput. Geosci. 2018, 111, 39-45. [CrossRef]

34. Panagos, P.; Borrelli, P.; Poesen, J.; Ballabio, C.; Lugato, E.; Meusburger, K.; Montanarella, L.; Alewell, C. The new assessment of soil loss by water erosion in Europe. Environ. Sci. Policy 2015, 54, 438-447. [CrossRef]

35. Lane, L.J.; Hernandez, M.; Nichols, M. Processes controlling sediment yield from watersheds as functions of spatial scale. Environ. Model. Softw. 1997, 12, 355-369. [CrossRef] 
36. Verstraeten, G.; Poesen, J. Factors controlling sediment yield from small intensively cultivated catchments in a temperate humid climate. Geomorphology 2001, 40, 123-144. [CrossRef]

37. Verstraeten, G.; Poesen, J.; de Vente, J.; Koninckx, X. Sediment yield variability in Spain: A quantitative and semiqualitative analysis using reservoir sedimentation rates. Geomorphology 2003, 50, 327-348. [CrossRef]

38. De Vente, J.; Poesen, J. Predicting soil erosion and sediment yield at the basin scale: Scale issues and semi-quantitative models. Earth-Sci. Rev. 2005, 71, 95-125. [CrossRef]

39. QGIS. A Free and Open Source Geographic Information System. Available online: http://www.qgis.org/ (accessed on 6 November 2017).

40. Neteler, M.; Bowman, M.H.; Landa, M.; Metz, M. GRASS GIS: A multi-purpose open source GIS. Environ. Model. Softw. 2012, 31, 124-130. [CrossRef]

41. Tebano, C.; Pasanisi, F.; Grauso, S. QMorphoStream: Processing tools in QGIS environment for the quantitative geomorphic analysis of watersheds and river networks. Earth Sci. Inf. 2017, 10, 257-268. [CrossRef]

42. National Geoportal. Access Point to Environmental and Territorial Information. Available online: http:/ / www.pcn.minambiente.it/mattm/en/ (accessed on 6 November 2017).

43. Hadley, R.; Schumm, S. Sediment sources and drainage basin characteristics in upper cheyenne river basin. In US Geological Survey, Water Supply Paper No. 1531-B; US Government Printing Office: Washington, DC, USA, 1961.

(C) 2018 by the authors. Licensee MDPI, Basel, Switzerland. This article is an open access article distributed under the terms and conditions of the Creative Commons Attribution (CC BY) license (http://creativecommons.org/licenses/by/4.0/). 